\title{
Phoenix industries and open innovation? The Midlands advanced automotive manufacturing and engineering industry
}

\author{
Philip Amison (Loughborough University) \\ David Bailey (Aston Business School) \\ Contact: P.D.Amison@lboro.ac.uk and d.bailey@aston.ac.uk
}

\begin{abstract}
This paper explores the links between open innovation and the emergence of a "phoenix industry' centred on the UK's traditional automotive heartland, the West Midlands, which has developed a significant presence in automotive design and engineering, particularly among small and niche firms. Drawing on case study research, the paper investigates whether this can be considered as a phoenix industry, and to what extent open innovation has been important in the industry's development. The paper considers relationships between firms and impacts in terms of changing economic and labour market conditions. The paper concludes by examining the role that public policy has played to date and might play in the future in supporting an emerging phoenix industry with open innovation features.
\end{abstract}

Keywords: Phoenix Industries, Open Innovation, Clusters, Advanced Manufacturing, Industrial Policy, Automotive Industry

JEL Codes: R58, R11, R28, L52, L62

\section{Introduction}

Phoenix industries have been described as clusters of small and medium-sized businesses working with broadly similar technologies that have sprung up in former industrial areas. They benefit from the historic, relatively immobile, investments in industry knowledge and workforce skills that have taken place over a long period of time in these areas. They typically research, develop and produce sophisticated components for use in a range of industries and hence are sometimes described as 'enabling industries'. Christopherson (2009; 79) describes them as benefiting from 'initial advantage' including "personal networks, technical skills and market knowledge that have developed over a long time, giving them an edge over less 'rooted' clusters in the same industry." Such phoenix industries can be seen as a potential escape route from 'negative lock-in' for old industrial regions on a declining development path - either as a source of 'escape' from an existing path or as offering a more positive, evolutionary path.

Simultaneously, in certain industries, it is argued that the process of innovation has become increasingly 'open' (Chesbrough, 2003), shifting from taking place within a single firm to 
taking place across firm boundaries - involving other firms, universities, research institutes and end users. For individual firms, such an approach enables an extension of the pool of knowledge and competencies on which they are able to draw. This is particularly relevant for industries or technologies where knowledge is widely distributed and firms cannot establish or maintain sufficient in-house capabilities. Such 'open innovation' approaches, it has been argued, can raise profits, increase speed to market, enable firms to expand their markets and are seen as desirable at times of rapid technological change (Chesbrough and Crowther, 2006).

In the automotive industry, the innovation process has traditionally been shaped by the vehicle makers and has mostly been undertaken in-house (Jürgens et al, 2008). However, as the range of technologies that are important to success in the industry has expanded in the light of environmental, regulatory and demand-led challenges - ranging from electronics, to digital, to new fuel and power technologies, and to lightweighting - the role of specialist suppliers of knowledge, R\&D and components has become crucial for innovations of a more systemic nature (Köhler et al, 2012).

This paper explores the links between open innovation and the emergence of a phoenix industry centred on the UK's traditional automotive heartland, the West Midlands. While the region has suffered significant deindustrialisation since the 1970s, particularly in the automotive sector, it has developed an important presence in automotive design and engineering, particularly among small and niche firms. After setting the scene in section 2 , by providing the historical context for the industry, section 3 discusses the phoenix industry and open innovation concepts and outlines the case study research used to explore the nature of the current industry. In section 4 the paper investigates whether the advanced automotive manufacturing and engineering cluster centred on the region can be considered as an example of a phoenix industry. It then explores to what extent open innovation has been important in the industry's development in section 5, and goes on to look at relationships between firms and impacts in terms of changing economic and labour market conditions in section 6 . The paper concludes by summarising the main findings from the research and looks at the role that public policy has played to date and might play in the future.

\section{The West Midlands auto industry}

The West Midlands was the birthplace of the automotive industry in the UK. During the 1960 s, the region was second only to the South East in terms of overall economic prosperity. 
Through the 1970s and early 1980s, however, the West Midlands' auto industry declined. Failing to secure any of the major Japanese inward investments to the UK that took place during the late 1980 s and 1990 s, its share in total UK automotive production fell from $75 \%$ at the start of the 1970 s to just $18 \%$ by 2008 (see Figure 1, below). There were major firm closures in the 2000s, including the final loss of volume manufacturing to the region in 2005 with the closure of MG Rover (Bailey et al, 2010 and 2012). The West Midlands automotive sector is now largely reliant on small-scale luxury vehicle production plus a number of specialist niche firms (Donnelly et al, forthcoming).

The region has remained important, however, as a centre for automotive design and engineering expertise. This includes the aforementioned vehicle makers in the premium and upper premium segments; a cluster of first and second tier suppliers; a number of niche vehicle manufacturers; and a concentration of design, R\&D and engineering consultancies plus university research expertise (Jarvis et al, 2012). The public policy environment has also been supportive of the industry, for example through the work of the former Regional Development Agency, Advantage West Midlands, during the 2000s and more recently the Automotive Council UK, a joint industry-government body established in 2009 and tasked with transforming the business environment for the industry nationally. More recently still, a national strategy for the automotive sector has been produced (HM Government, 2013), put together on the basis of joint working between government and the industry.

The last few years have seen an upturn in the fortunes of the automotive sector in the UK. Between 2009 and 2012 car production increased by around 50\% (Society of Motor Manufacturers and Traders (SMMT), 2013). The industry in the West Midlands has also benefited with the most significant firm in the region, Jaguar Land Rover (JLR), also expanding. Indeed, over the last three years JLR has created nearly 11,000 direct new jobs with some 6,000 in the regioni. The impact of the associated turnaround in production volumes is illustrated in Figure 1. Around half of the recent increase in UK automotive output over 2009-2013 can be accounted for by JLR. 
Figure 1 - Car manufacturing output volumes in the UK and the West Midlands, 1970 - 2012

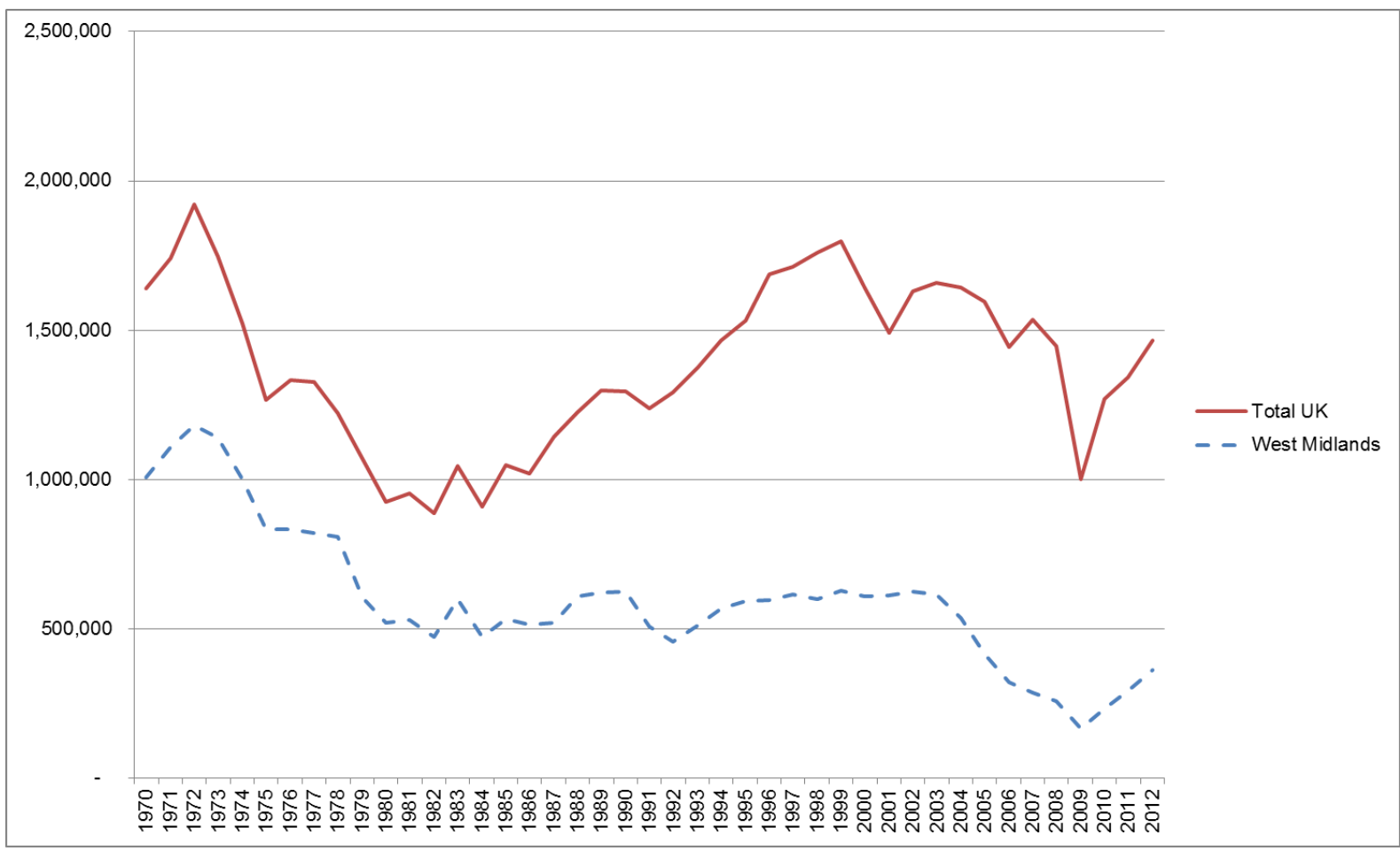

Source: Adapted from Donnelly et al (forthcoming) and updated using data from the SMMT and Jaguar Land Rover Investor Presentation reports

\section{Phoenix industries and open innovation}

Phoenix industries

The notion of phoenix industries - clusters of small and medium-sized businesses, working with broadly similar technologies, that have sprung up in former industrial areas - is related to the wider literatures on regional economic trajectories. Whether they are viewed as providing radical or evolutionary change varies depending on how tightly the initial definitions of a region's industrial strengths are framed. More narrow, static, definitions of existing cluster strengths make it less likely that opportunities for inter-industry evolution and growth will be identified. This has led some authors to question the validity of cluster-based approaches to regional development arguing, instead, the need for a more holistic approach (for example, Martin and Sunley (2003, 2006); Sadler (2004); and Treado (2010)). A number of factors are identified in the literature as being important to the development of a phoenix industry in an old industrial area. These include the presence of relevant skills in the local labour force and in (potential) supplier firms; technical skills and expertise in nearby colleges, universities and other training or research facilities; personal networks and market knowledge related to the industries concerned; capital for investment; and reputational 
factors. Each is explored in more detail in section 4, in the context of the advanced automotive manufacturing and engineering industry centred on the West Midlands.

\section{Open innovation}

Reflecting on the explosion of interest in open innovation, since he first wrote about the concept in 2003, Chesbrough describes how it has become, "a new paradigm for organizing innovation ... firms can and should use external ideas as well as internal ideas, and internal and external paths to market, as they look to advance their innovations" (2012; 21). In later work focusing in lower technology and more mature industries, Chesbrough and Crowther (2006) found that the firms they interviewed used open innovation to address two quite different growth objectives - potential growth within the current business (incremental change) and potential growth in new business areas (step change).

In the case of firms seeking growth within the current business, according to Chesbrough and Crowther, some firms stated that it was quicker and cheaper for them to look outside the business for the new technology required than to develop it in-house. Turning to firms pursuing growth in new business areas - so-called 'breakout business' - Chesbrough and Crowther characterise the issue for large firms as one of avoiding over-funding of incremental business projects and under-funding of longer-term but potentially higher growth possibilities. As the latter are high risk, they found that companies seek to spread their risk by placing a series of small 'bets' on unproven technologies. The extent to which open innovation approaches of the type identified by Chesbrough and Crowther are evident in the auto industry centred on the West Midlands is explored further in section 5.

\section{Phoenix industries and open innovation: Commonalities and differences}

The two concepts - phoenix industries and open innovation - share some commonalities. Phoenix industry firms are described as working with broadly similar technologies, developing sophisticated components for use in a range of industries. There is a broad potential fit between this and the open innovation concept of a set of firms drawing upon a wide pool of competencies, within and outside firm boundaries, using a mix of internal and external paths to market. Another area of commonality lies in the related notions of labour mobility and knowledge transfer, important in both concepts. Phoenix industry firms are reliant on the existence of a pool of relevant skills, technical and market knowledge in the local labour force and in supplier firms. Similarly, Chesbrough (2012) identifies workforce mobility as a necessary condition for open innovation to be successful, arguing that to move knowledge you need to be able to move people. 
Turning to areas in which the two concepts may work in opposition, implicit within the open innovation concept is an interrelation between large and smaller firms - in particular, the use of small firms, by larger firms, to assist in advancing the large firms' innovations. Conversely, in the phoenix industries concept small firms are seen as replacing the older, larger firms that once dominated the area. Another potential area of difference between the two concepts lies in the reliance of phoenix industry firms on a pool of workforce skills that relate to the area's industrial past. In contrast, open innovation is suggested to be particularly relevant for industries or technologies where knowledge is widely distributed and at times of rapid technological change. The implication is that firms require (access to) highly skilled labour, with up to date knowledge of the latest technologies in order to succeed. These areas of commonality and difference between the concepts of phoenix industries and open innovation are explored further below.

\section{A case study of advanced automotive manufacturing and engineering firms}

The remainder of this paper draws upon a case study of firms operating within the advanced automotive manufacturing and engineering industry centred on the West Midlands/Midlands ii region of the UK. It builds upon earlier work on the West Midlands automotive cluster (Jarvis et al, 2012; Berkeley et al, 2012) and draws comparisons with previous studies of old industrial areas, including Christopherson and Clarke (2007), Christopherson (2009) and, most notably, Treado's work on the Pittsburgh steel cluster (2010). The study introduces a new dimension by combining phoenix industry and open innovation conceptual frameworks.

Initially focusing on firms involved in the 'low carbon vehicles' sector, a long list of around eighty firms were identified based on information gleaned from industry bodies and networks. These firms sit within a broader concentration of advanced automotive manufacturing and engineering activity across the Midlands and extending south into the overlapping motorsport clusteriii. A structured interview approach was adopted on the basis that it would yield richer information and a better response rate than either written or telephone surveys. Because of the difficulty of securing interviews, participants were not selected on the basis of a sampling approach. Seventeen firms agreed to be interviewed, plus a further three interviews were completed with other stakeholders in the sector ${ }^{\text {iv }}$.

The firms interviewed cannot, necessarily, be considered to be representative of the sector as a whole and the results must therefore be considered indicative, rather than definitive. The firms interviewed did, however, constitute a good spread by size (ranging from micro to large firms), turnover (ranging from pre-revenue to those making over £50 million per annum) and by activity and area of technology. They included firms involved in vehicle and 
component design, development, manufacturing and repair; and engineering services providers, including some offering consultancy and/or testing facilities. They spanned a range of technologies including those needed for hybrid and electric vehicle development; battery and hydrogen fuel cell technologies; and the use of new materials for example to produce lightweight structures. The start dates of the firms interviewed ranged from the $19^{\text {th }}$ Century to as recently as 2009. The majority of firms started up in the period $1999-2009$.

\section{Advanced automotive manufacturing and engineering firms in the Midlands - An example of a phoenix industry?}

The factors identified in the literature as being important to the development of a phoenix industry, as described previously, include the presence of relevant skills in the local labour force and in (potential) supplier firms; technical skills and expertise in nearby colleges, universities and other training or research facilities; personal networks and market knowledge; capital for investment; and reputational factors. Each is discussed in turn below in the context of the Midlands case, and comparisons are made with previous studies of old industrial areas.

Relevant skills in the local labour force and in (potential) supplier firms

Christopherson (2009) describes how advanced manufacturing firms can find the necessary expertise, capital and labour force skills to be able to innovate and expand in places where there have been long-term investments in industry knowledge and workforce skills. These are typically areas where there are many firms working with broadly similar technologies. The Midlands can be seen as such an area, where significant investments have been made over a long period of time related to the automotive sector. The interviews conducted with firms confirm the importance of industry expertise and workforce skills, though the role of capital is more uncertain as is discussed further, below, and may provide limits to the development of the industry.

Treado (2010) examines the successful transition of Pittsburgh, in the United States, from a steel making town to home to a successful steel technology cluster. Although the area lost most of its steel-making capacity, it did not lose its steel-making expertise. She identifies the key factors in this transition as being the area's location, its industrial legacy and its labour expertise. According to Treado, the ultimate source of regional resilience in the Pittsburgh case - and in the other studies she has reviewed - is the surviving industrial expertise of the regional workforce. Here, the technical knowledge of the workforce was the overriding 
reason given for a firm's choice of location in the Pittsburgh area. In the Midlands case the results from the interviews also support the view that skills retained in the labour force and in local supplier firms are important to firms in the sector. Along with proximity to customer firms (itself related to the historic presence of the automotive and motorsport industries in the region), these were often cited as important factors influencing a firm's choice of location. The presence of relevant skills in the labour force was not such a dominant factor across the firms interviewed, however, as Treado found in the case of Pittsburgh. In part this perhaps reflects the greater internationalisation of the labour market in the Midlands case. Many firms, for example, said they had already exhausted the local supply of specialist skills they required, and were having to recruit internationally. It is possible that the presence of specialist skills in the local labour force was of greater importance to those firms that were more oriented towards making physical products. Firms whose workforce comprised a greater proportion of higher-level professional and technical roles were more likely to be recruiting on a UK-wide or international basis for the specialist skills they required particularly where they were working in relatively new or emerging areas of technology.

\section{Technical skills and expertise}

Christopherson (2009; 78-9) characterises phoenix industry firms as benefiting from initial advantage'. This makes them different from more traditionally described industry clusters. Specifically, such firms are seen as benefiting 'from personal networks, technical skills and market knowledge that have developed over a long time' (ibid). Hence, although many routine production jobs have been lost in these industries, the knowledge of how to produce and innovate has remained to some extent. This could be, for example, in the courses run by local universities and in the skills of the labour force. Similarly, Treado (2010) highlights the importance of Pittsburgh's broader tradition of expertise in materials-based industries, for example the expertise contained within the engineering departments of the region's major universities, plus the location of a number of major private sector research facilities in the region, and the fact that several important trade associations and relevant professional societies are headquartered there.

The West Midlands lost many routine production jobs in automotive and related industries over the period since the 1970s. In the 1960s there were more than 1 million manufacturing jobs in the region. By 2013 the number had fallen to just over 300,000. ${ }^{v}$ The results from the interviews support the argument that specialisms retained within local universities are important to the automotive sector in the region. Firms were asked about the extent to which they collaborated with universities and whether they selected university partners on the basis of proximity or on grounds of excellence in relevant specialisms, irrespective of location. 
Even though many firms said they collaborated with universities on the basis of excellence in relevant specialisms, rather than proximity, the most frequently named universities that firms said they had collaborated with were in fact local to the area - in Coventry, Warwick, Loughborough, Oxford and Birmingham. It is also worth noting that linkages with universities appear to be more important to the firms interviewed in the Midlands case than, for example, Treado found to be the case for the Pittsburgh firms. This may in part be due to the important role that state-funded collaborative R\&D projects have played in the Midlands case. This point is considered further below.

In addition to the importance of expertise retained within local universities, in the Midlands it is also the case that a number of private sector automotive firms have chosen to locate, or retain, significant research facilities within the region - for example Jaguar Land Rover, Tata Motors, MIRA (including its Technology Park) and Ricardo UK all have significant R\&D facilities in the Midlands. In addition, there have been a number of more recent investments in public-private research facilities such as the Manufacturing Technology Centre, the High Value Manufacturing Catapult (a technology and innovation centre) and forthcoming developments such as the National Automotive Innovation Campus at Warwick University and the Manufacturing Institute being created by Coventry University in partnership with Unipart Group. Taken together, this is an impressive collection of automotive and engineering-related expertise, or 'innovation assets' as they are described locally. In the Pittsburgh steel case, Treado noted that a number of trade associations and professional societies were headquartered in the Pittsburgh area. This is not the case for the Midlands. In the UK such bodies tend to be headquartered in London, in some cases with regional offices. This perhaps reflects the greater centralisation of activity - and the economic dominance of London and the South East - in the UK.

\section{Personal networks and market knowledge}

The 'initial advantage' of phoenix industry firms includes personal networks and market knowledge that have developed over a period of time (Christopherson, 2009). Of the firms interviewed in the Midlands case, a number of the owners or founders did have connections and experience rooted in the automotive sector. In some cases they had previously been employed by larger firms in the sector and it is likely that they continued to have contacts in these or successor firms. Their knowledge of market opportunities was also important. There were a number of cases in which a new firm had been established by - or with the support of - people who had previously been employed by larger firms in the sector who had identified a new market opportunity. There was also some evidence of 'forced' start-ups, for 
example as a result of people being made redundant from the larger firms as they downsized or went out of business.

\section{Availability of capital}

Christopherson (2009) references the availability of capital as a factor that may contribute to the establishment of a phoenix industry. In the Midlands case, rather than being a supporting factor, lack of access to capital has been a drag on the sector. This is partly a result of the recent 'credit crunch' but there are also longer-term and sector-specific factors at play. Domestic finance for investment in manufacturing has been a problem for British industry, stretching as far back as the late $19^{\text {th }}$ Century (for example, as described by Miozzo and Walsh (2006; 64-5) who cite work by Elbaum and Lazonick, 1986; Freeman, 1989; Landes, 1969; Hobsbawm 1968). Several interviews expressed the belief that, "there is no finance available in the UK for manufacturing".

In addition, access to finance can be a particular problem for automotive sector firms in the UK. The sector has traditionally been seen as high risk by the banks. There are complicating factors associated with the complexity of supply chains, in particular with regard to finance for tooling, where the asset specificity of tools means that banks are often unwilling to accept the tools as collateral. This is exacerbated when the industry picks up and orders flow down the supply chain, given the long time-lag between the purchase of the tool and the flow of cash from final assembly, combined with the uncertainty over future volumes (The Smith Institute \& SMMT, 2012). This issue was recognised in the recently produced government/industry strategy for the automotive sector (HM Government, 2013; 49-50).

\section{Reputation}

Treado (2010) argues that regions such as Pittsburgh, with a strong reputation in a particular industry or set of industries, may find reputation-building easier than other regions. Although globalisation has increased the range of possible locations where production may take place, it has also increased the search costs of finding the right supplier (ibid). The location of a supplier within a well-known cluster can therefore act as a signal that purchasing firms may use to help narrow their search options. There was evidence of this effect in the Midlands case. Several firms mentioned the branding or reputational benefits of being located in the area. One firm also highlighted the importance of the growing reputation of British engineering - a relatively new phenomenon. British engineering would not have been viewed as synonymous with quality or innovation during the period of decline that set in 
during the 1970s. It would be interesting to establish when, and for what reasons, the turnaround in reputation began to take place.

\section{The role of technology and innovation, supply chain relationships and the importance of the ability to apply new technologies}

The role of technology and innovation in driving the sector

Whitmarsh and Köhler (2010) argue that the auto industry has become 'locked-in' to the core technologies and practices around the internal combustion engine and steel chassis development through a combination of complex supply chain arrangements, sunk investments in equipment, the existing skill set of the labour force and an industry-wide technological paradigm. As a result, the incumbent firms tend to favour incremental innovation focused on the improvement of existing technologies. More radical innovation, for example around battery or fuel cell powered vehicles, has tended to be initially undertaken, "within universities, by firms in other sectors or by enthusiastic amateurs, entrepreneurs or start-ups" (2010; 431). The automotive industry has tended to enter into partnerships with organisations outside the industry in order be able to move beyond their core competencies and utilize expertise from outside the sector.

As described in section 3, Chesborough and Crowther's (2006) work suggests that firms might deploy open innovation approaches to address both incremental and step change (breakout) growth strategies. In the case of firms seeking (incremental) growth within the current business, according to Chesbrough and Crowther, some firms stated that it was quicker and cheaper for them to look outside the business for the new technology required than to develop it in-house. This matches a view expressed by several of the interviewees in the Midlands case; that smaller firms could often develop and test a new idea more quickly and cheaply than the larger firms.

Evidence from the interviews also very much supports the view that smaller and medium sized firms in the Midlands are playing an important role in providing the more radical innovation needed for systemic change in the automotive sector. "We need to be constantly innovating to attract the attention of customers", said one firm. The majority of the smaller and medium sized firms interviewed were suppliers of innovation to the larger automotive firms. In some cases they were working at the leading edge of a particular technological area - typically an area that fell outside the traditional automotive sector competencies. For 
example, when asked how they kept up to date with technological and industry developments, one firm replied, "We are at the leading edge".

More generally, Frigant (2013) notes that several of the major automotive firms (including BMW, PSA, Ford and GM) have established venture capital operations, targeted on funding innovative start-ups capable of providing original solutions in new technological areas. This matches Chesborough and Crowther's (2006) characterisation of 'breakout business' growth strategies, whereby larger firms spread their risk by placing a series of 'small' bets on unproven technologies. Over the past decade, the breadth of technologies important to automotive engineering has increased the opportunities for new firm entry to the sector.

\section{Supply chain relationships}

In their study of global value chains in the automotive industry, Sturgeon et al (2008) note that regional automotive clusters tend to be very long-lived because of the deep investments that have to be made in capital equipment and skills. They distinguish a number of ways that firms coordinate or govern the linkages between value chain activities. These are defined in terms of combinations of three distinct variables: the complexity of information to be exchanged between value chain tasks; the codifiability of that information; and the capabilities resident in the supply base (based on Gereffi et al., 2005). The most interesting of these linkages, from the perspective of the Midlands case study, are the so-called 'relational' linkages, where tacit information is exchanged between buyers and highly competent suppliers. Sturgeon et al (2008) examine the persistence of the greater Detroit vehicle development cluster. They note that the increased involvement of suppliers in vehicle design - as a result of the importance of relational linkages in the auto industry - has led to a spatial concentration of supplier design and engineering facilities. In North America this spatial concentration has been focused on the Detroit area because of its historic role as a centre for vehicle design and engineering. The area continues to host specialist labour and a number of institutions that support automotive engineering. Suppliers need to be located in the cluster in order to gain opportunities to become involved in new vehicle development programmes. Hence the cluster has been reinforced despite the fact that final vehicle assembly activity, in which the area was originally dominant, has moved away.

Frigant (2013) notes the trend over recent decades for automotive supply chains to become increasingly dominated by large 'mega-supplier' firms. He argues that SMEs still have an important role to play, however. They are often used by the large auto firms to provide specialist equipment or services, such as design. In the case of niche vehicles and special series production, in particular, manufacturers typically rely on short production runs that are 
of less interest to the major equipment suppliers. Frigant notes that SMEs also have an important role to play in innovation. As described above, the larger firms tend not to have the necessary competencies to cover all areas of technology.

In the context of the Midlands auto industry, as noted previously, the West Midlands failed to secure any of the major inward investments by the volume car producers that have taken place in the UK since the 1980s. The region had already progressively lost much of its domestic vehicle production. It did manage to retain all stages of the production process including research and development - in its leading (low volume) vehicle producer, Jaguar Land Rover (JLR). JLR was highlighted as an important customer for a number of the firms interviewed. In these cases it is likely that the value chain linkage is 'relational', with close working required between supplier and customer. Several firms cited proximity to their major customer (JLR) as the most important factor in their choice of location. Many of the firms interviewed also worked with other major German and Japanese auto firms, however - firms without a production base in the Midlands. Although not on the scale of the Detroit cluster, the West Midlands has followed a similar pattern in the sense that it has been able to retain and continue to attract suppliers of vehicle design and engineering services, despite the loss of volume vehicle production to the region.

\section{The ability to apply new technologies}

Christopherson (2009; 78) argues that industries in old industrial areas may have "the key assets needed to support process and product innovation and the actual application of new technologies." There is evidence from the interviews conducted with firms in the Midlands that, in a number of cases, the specific skills necessary to produce innovative products or components were embedded within firms' workforces. In some cases, this was the principal means of protecting the firm's intellectual property. These were typically firms that also had a tradition of long service within the workforce. In one case, for example, until relatively recently the average length of service of employees had been over 40 years. The retention of relevant skills within the labour force, despite the loss of many of the larger firms that once dominated the region, is one of the primary factors cited as contributing to the development of a phoenix industry. As the workforce ages, however, those skills are gradually lost. A number of the firms interviewed noted that the younger generation of workers did not have the same practical skills as their older colleagues. Clearly there is a balance, in the sense that new knowledge and skills are also required for the development and exploitation of new technologies. To some extent, therefore, the phoenix industry firm can be seen as an environment in which knowledge and skills related to 'old' and 'emerging' technologies are combined. Physical products, largely, still have to be developed, made and tested to prove 
their worth - they cannot just be designed. It is this ability to combine 'old' and 'emerging' technologies that appears to have contributed to the success of a number of the firms interviewed and, perhaps, lies at the heart of the relationship between the phoenix industry and open innovation concepts.

The 'initial advantage' possessed by phoenix industry firms and their ability to develop and apply new technologies means that they can have an important role to play in the deployment of 'smart specialisation' strategies (Foray and Van Ark, 2007). According to this approach, rather than spreading their investment in R\&D and innovation thinly across several frontier technology research fields, EU countries or regions should instead concentrate their investment in programmes that complement their existing productive assets. The European Commission has recently (2010) called for national and regional governments to develop smart specialisation strategies, as an important component of the Europe 2020 Strategy. In order to achieve this, McCann and Ortega-Argilés $(2011 ; 18)$ argue the need for policy at regional level to "promote technological diversification amongst the most embedded industries which have the relevant scale to generate significant local impacts". The advanced automotive manufacturing and engineering sector is in this sense seen as an important focus in a smart specialisation strategy for the Midlands, though questions remain about its ability to generate significant local labour market impacts, a point that is returned to in the next section.

\section{Relationships between firms and changing economic and labour market conditions}

\section{Relationships between firms}

Treado (2010) comments on the sometimes positive effect of the exit of formerly dominant large firms from an area. She cites work by Waluszewski (2004) on the biotech cluster in Uppsala, Sweden and Christopherson and Clark's (2007) study of the optics and imaging cluster in Rochester, New York. In both cases the existing large firms played a role in holding back the development of smaller firms because of their greater ability to secure resources such as skilled labour and access to the research infrastructure. In the Midlands case there is evidence to support that view that smaller firms find it difficult to compete with the larger firms for skilled labour. These larger firms are also typically, however, their customers or potential customers and frequently may also be partners in research projects. Indeed, an important feature of the sector was the extent of collaboration between firms, encouraged by state-supported collaborative R\&D projects. In addition to reducing the cost of undertaking $R \& D$, firms also benefited from participating in these projects because of the 
opportunities they afforded for identifying and working with firms that could subsequently become partners, suppliers or customers in fully commercial ventures.

In Treado's (2010) work on the Pittsburgh steel technology cluster, member firms were linked by the market that they supply rather than the product they produce. All of the firms sold to the steel industry but rarely did they sell exclusively to that industry. A corresponding pattern was found in the Midlands firms studied. Many of the firms interviewed served industries beyond automotive. The most often named customer industries were aerospace, defence and motorsport but firms were also involved in supplying industries such as renewable energy and medical technology. The more diversified nature of these firms' markets, particularly when compared to their large-firm predecessors, should mean that the economy of the local area is more resilient to single-industry shocks - and may be seen as a response to previous industry shocks. It also opens up possibilities for further diversification of the region's portfolio of industries, increasing related variety, which is expected to enhance regional growth (Frenken et al., 2007).

\section{Changing economic and labour market conditions}

In the West Midlands many of the large automotive sector firms have disappeared over time. The firms that remain and the new firms that have been created - including those that were interviewed in this case study - employ fewer, but generally more highly skilled workers. Around 700,000 manufacturing jobs have disappeared from the region since the $1960 \mathrm{~s}$. Employment in other sectors, notably in public and private service industries, has risen. This has had important implications for the region's economy and labour market in terms of the number jobs, the opportunities at different occupational levels, the associated skill requirements and the wage levels that are available to residents. Bailey et al (2012), for example, found that workers who lost their jobs as a result of the closure of the MG Rover factory at Longbridge in Birmingham in 2005 typically found it difficult to go back into manufacturing employment and the majority suffered significant reductions in earnings, relative to their previous roles at MG Rover. Whereas Treado writes of a mutually beneficial exchange - in which employers have access to many workers and workers have access to many job opportunities - the situation facing former automotive sector workers in the West Midlands over the last decade has been somewhat less balanced in their favour. 


\section{Conclusions and the role for public policy}

The story of the automotive sector in the Midlands, and the West Midlands in particular, stretches over more than a century. During this period the industry emerged, grew to dominate the region's economy and then began a steady decline which culminated, in 2005 , with the loss of all volume production to the region. It is possible that the decline of the industry in the region is now beginning to be reversed. This paper has explored the extent to which the advanced automotive manufacturing and engineering sector in the Midlands can be understood as an example of a phoenix industry. An important question in this regard is the role that the re-emergence of JLR has played and whether this conforms with the notion of a phoenix industry?

JLR has certainly been important to many of the firms interviewed, but this is not just about rising production volumes creating increased demand for suppliers. It is also to do with JLR's role as a niche/luxury vehicle producer and one that carries out all stages of production and development activity in the area. This has created a space for specialist suppliers and technology developers that, thus far, have not been sufficiently attractive to be filled by the 'mega-supplier' firms. Would these smaller firms still choose to locate in the area if JLR were no longer there? In the authors' view it is likely that they would. There is a sufficient agglomeration of automotive and motorsport-related activity and expertise in the area to attract and retain these firms. In addition, a number of the firms interviewed were already serving major German and Japanese automotive manufacturers, indicating an ability to compete internationally at the highest level.

Historic, and relatively immobile, investments in the Midlands related to the automotive industry have been important influences on the location decisions of the firms interviewed. However, innovation and technical change have also been important drivers. The range of technologies now important in the automotive sector has brought opportunities for the entry of new firms. Uncertainty about which technologies will come to dominate, combined with the range of specialism involved has encouraged larger firms to engage with a wider range of potential collaborators. This has meant that there are now more direct interactions between firms at different levels in the supply chain, between large and small firms, and between firms specialised in different technological areas.

It was argued that small firms can often innovate more quickly and more cheaply than the major auto firms, bringing new ideas to the prototype or demonstrator stage. This was seen by some as a particular characteristic of small firms in the UK. On the other hand, making the step up from prototype or demonstrator to full scale production was viewed as an area in 
which the UK is weak. This is compounded by the uncertainty surrounding the commercialisation possibilities for these new technologies. The necessary investment to bring a new product idea into production is harder to attract because of the associated level of risk. This was also viewed as a critical problem even for larger firms. Ironically, therefore, whilst the breadth of technologies that may be important has opened up opportunities for new entrants to the sector, the associated uncertainty around which technologies will ultimately come to dominate has also made it more difficult for smaller firms to attract the necessary resources to grow their businesses.

From an industrial policy perspective, state funding for (collaborative) R\&D projects was important for most of the firms interviewed. The funding has enabled more innovation to take place; encouraged greater collaboration; helped large and small firms to identify new potential partners; and helped smaller firms identify potential customers and potentially enter new supply chains. A number of interviewees considered that there was 'enough' support available for early stage R\&D. The area where more intervention is needed, they suggested, was support for moving from the prototype or demonstrator stage to production version and from there onto full commercialisation of the new product idea.

In terms of the more traditional areas for public sector intervention, the ability to recruit suitably skilled staff was an issue for many firms. This was particularly the case in the new technology areas. Several firms stated, however, that it was difficult to predict skills needs in specific areas very far in advance. Access to finance was also identified as a key constraint by a number of firms - either investment finance in order to be able to expand the business, or assistance with cash flow in the context of being able to make up front investments necessary when taking on new projects.

Finally, in terms of the role of industrial policy, greater and more effective collaboration between industry and government has been important in the development of the sector to date. The former Regional Development Agency (RDA), Advantage West Midlands, developed a number of interventions, initially in response to the Rover crises of 2000 and 2005 but increasingly through closer collaboration using a cluster-based approach. With the demise of the RDAs a number of these initiatives have been taken forward by national agencies, such as the Technology Strategy Board; and by local actors such as the Niche Vehicle Network and relevant Local Enterprise Partnerships (LEPs). It remains to be seen, however, whether the LEPs are of sufficient scale - or will be able to co-ordinate cross-LEP activity - to work effectively with firms in a sector whose footprint spans at least six LEP areas. vi 
The work of the Automotive Council, established in 2009, was seen to have been important by a number of interviewees. This included long-term direction-setting for the industry, through the Council's technology road-mapping work; informing the setting of regulation and standards at national and international levels and the work to support the development of the supply chain in the UK. Funders such as the Technology Strategy Board and the Niche Vehicle Network were also praised for their approach in drawing upon industry input in the design and execution of funding programmes. This suggests a positive role for industrial policy in terms of bringing actors together in a discovery process, and in terms of the possibilities of building smart specialisation strategies and industrial policies which are aligned with 'high-road strategies'vii.

In terms of a future research agenda, in the Midlands context more work could be undertaken to clarify the importance of JLR to firms in the sector; and what the impact might be should the firm's international owners decide to move some or all of JLR's activity outside the region. It would also be interesting to explore critiques of the concept of open innovation (for example, see Oakey (2013)), in particular with regard to its relevance for hightechnology small firms and the behaviour of such firms in different sectors such as automotive, bio-tech and IT.

\section{Acknowledgement}

The research underpinning this paper has been supported by the European Commission's $7^{\text {th }}$ Framework Programme through the 'Welfare, Wealth and Work for Europe' (wwwforEurope) Collaborative Project, Grant Agreement number 290647.

\section{References}

Bailey, D., de Ruyter, A., and Clarke, I. (2010). Private Equity and the Flight of the Phoenix 4? The Restructuring, Collapse and Impact of MG Rover in the West Midlands, Cambridge Journal of Regions, Economy and Society, 3(3), 367-382.

Bailey, D., Chapain, C. and de Ruyter, A. (2012) Employment outcomes and plant closure in a post-industrial city: An analysis of the labour market status of MG Rover workers three years on, Urban Studies, 49(7), 1595-1612.

Berkeley, N., Jarvis, D. and Begley, J. (2012) Phoenix from the ashes: can low carbon vehicles ensure the long-term viability of the West Midlands automotive cluster?, International Journal of Automotive Technology and Management, Vol. 12, No. 2, 137-152. 
Chesbrough, H. (2003) Open Innovation: The New Imperative for Creating and Profiting from Technology. Boston, Mass.: Harvard Business School.

Chesbrough, H. (2012) Open innovation: Where we've been and where we're going, Research Technology Management, Jul/Aug, Vol. 55, Issue 4, 20-27.

Chesbrough H. and Crowther A.K. (2006) Beyond high tech: early adopters of open innovation in other industries, $R \& D$ Management $36,3$.

Christopherson, S. (2009) 'Building 'Phoenix Industries' in our Old Industrial Cities'. in The Future of Regional Policy. ed. by Tomaney, J. London: The Smith Institute, 78-86.

Christopherson, S. and Clark, J. (2007) The evolution of the optics and imaging industry, in Remaking regional economies: Power, labor, and firm strategies in the knowledge economy, Routledge, London.

Donnelly, T., Begley, J. and Collis, C. (forthcoming) The West Midlands automotive industry (1970 to 2008): the road downhill, Business History (forthcoming).

European Commission (2010) Regional Policy contributing to smart growth in Europe 2020, Communication from the Commission to the European Parliament, the Council, the European Economic and Social Committee and the Committee of the Regions, COM(2010) 553 final, 6.10.2010, Brussels.

Elbaum, B. and Lazonick, W. (1986) The Decline of the British Economy, Oxford, Clarendon Press.

Foray, D and Van Ark, B. (2007) Smart specialisation in a truly integrated research area is the key to attracting more R\&D to Europe, Knowledge Economists Policy Brief $n^{\circ} 1$ October 2007, Research Commissioner Janez Potočnik's Expert Group, European Commission.

Foray, D., David, P. A. and Hall, B. (2009) Smart specialisation: The Concept, in Knowledge for Growth: Prospects for science, technology and innovation, Selected papers from Research Commissioner Janez Potočnik's Expert Group, November 2009, European Commission.

Freeman, C. (1989) The Third Kondratieff Wave: Age of Steel, Electrification and Imperialism, in Bohlin et al (eds.) Samhällsvetenskap ekonomi och histoia. Göterborg: Daidalos. Shorter version published in Kihlstrom et al (eds.) Fetschrift in Honour of Lars Herlitz, Gothenberg.

Frenken, K.,Van Oort, F.,Verburg, T. (2007) Related variety, unrelated variety and regional economic growth, Regional Studies, 41, 685-697.

Frigant, V. (2013) Editorial: Putting SMEs back at the heart of automotive supply chain analysis, International Journal of Automotive Technology and Management, Vol. 13, No. 4, 2013.

Gereffi, G., Humphrey, J., Sturgeon, T. (2005) The governance of global value chains, Review of International Political Economy, 12(1): 78-104.

Hildrith, P. and Bailey, D. (2013) The Economics behind the Move to Localism in England, Cambridge Journal of Regions, Economy and Society, 6(2), 233-249. 
Hobsbawm, E. (1968) Industry and Empire: An Economic History of Britain since 1750, London: Weidenfeld \& Nicolson.

HM Government (2013) Driving success - a strategy for growth and sustainability in the UK automotive sector, Department for Business, Innovation and Skills and the Automotive Council UK, July 2013.

Jarvis, D., Berkeley, N. and Donnelly, T. (2012) Capturing the economic benefits of a transformative shift to low carbon automobility: A case study of the West Midlands, UK, Local Economy, 27 (7), 692-704.

Jürgens, U, Blöcker, A and MacNeill, S(2008). The Automotive Sector: Knowledge Stocks and Flows. EURODITE Working Paper. Birmingham: Centre for Urban and Regional Studies.

Köhler, J., Schade, W., Leduc, G., Wiesenthal, T., Schade, B., and Espinoza, L. T. (2012) 'Leaving Fossil Fuels Behind? an Innovation System Analysis of Low Carbon Cars'. Journal of Cleaner Production.

Landes, D. (1969) The Unbound Prometheus, Cambridge, UK: Cambridge University Press.

Martin, R. and Sunley, P. (2003) Deconstructing clusters: chaotic concept or policy panacea? Journal of Economic Geography, 3: 5-35.

Martin, R. and Sunley, P. (2006) Path dependence and regional economic evolution, Journal of Economic Geography, 6: 395-437.

McCann, P. and Ortega-Argilés, R. (2011) Smart Specialisation, Regional Growth and Applications to EU Cohesion Policy, Economic Geography Working Paper 2011: Faculty of Spatial Sciences, University of Groningen.

Miozzo, M. and Walsh, V. (2006): International competitiveness and technological change, Oxford University Press, Oxford.

Oakey, R. P. (2013) Open innovation and its relevance to industrial research and development: The case of high-technology small firms, International Small Business Journal, 31: 319 .

Rodrik, D. (2004) Industrial policy for the twenty-first century, John F Kennedy School of Government Working Paper Series, Harvard University, Cambridge MA.

Rodrik, D (2008) One Economics, Many Recipes: Globalization, Institutions, and Economic Growth. Princeton: Princeton University Press.

Sadler, D. (2004) Cluster evolution, the transformation of old industrial regions and the steel industry supply chain in North East England. Regional Studies, 38: 55-66.

SMMT (Society of Motor Manufacturers and Traders) (2013) Motor Industry Facts 2013. London: SMMT.

Sturgeon, T., Van Biesebroeck, J. and Gereffi, G. (2008) Value chains, networks, and clusters: reframing the global automotive industry. Journal of Economic Geography, 8: 297321. 
The Smith Institute \& SMMT (Society of Motor Manufacturers and Traders) (2012) Give them Some Credit! A Survey of the Barriers to Funding the UK's Automotive Supply Chain. London: The Smith Institute.

Treado, C. D. (2010) Pittsburgh's evolving steel legacy and the steel technology cluster, Cambridge Journal of Regions, Economy and Society, 3, 105-12.

Waluszewski, A. (2004) A competing or co-operating cluster or seven decades of combinatory resources? What's behind a prospering biotech valley? Scandinavian Journal of Management, 20: 125-150.

Whitmarsh, L. and Köhler, J. (2010) Climate change and cars in the EU: the roles of auto firms, consumers, and policy in responding to global environmental change, Cambridge Journal of Regions, Economy and Society, 3, 427-441.

\footnotetext{
i See http://www.smmt.co.uk/2013/09/major-boost-for-uk-car-manufacturing-as-jaguar-land-rovercreates-1700-solihull-iobs/ (accessed September, 2013)

"Some of the firms interviewed were located in neighbouring regions, hence the term 'Midlands' more appropriately describes the study area.

iii The Motorsport Industry Association estimates that there are around 4,500 companies involved in the UK Motorsport and Performance Engineering Industry, with the largest concentration of firms to be found within 'Motorsport Valley', a business cluster located in the middle of the UK, with Oxford at its centre (http://www.the-mia.com/The-Industry, accessed March 2014).

iv The interviews were conducted between April and August 2013.

$\checkmark$ UK Office for National Statistics.

vi See Hildreth and Bailey (2013) on the need for cooperation across LEPs.

vii This is largely how intelligent industrial policy design is conceived of in contemporary debates (see Rodrik, 2004; 2008), with policy having the quality of 'embedded autonomy', where it focuses on the discovery process, and with firms and the state learning about underlying costs and opportunities and engaging in strategic coordination.
} 